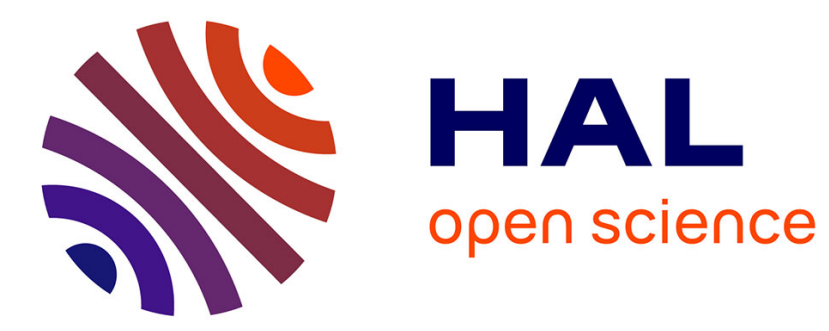

\title{
No evidence that habitat disturbance affects mating frequency in the giant honey bee Apis dorsata
}

Atsalek Rattanawannee, Chanpen Chanchao, Siriwat Wongsiri, Benjamin

Oldroyd

\section{- To cite this version:}

Atsalek Rattanawannee, Chanpen Chanchao, Siriwat Wongsiri, Benjamin Oldroyd. No evidence that habitat disturbance affects mating frequency in the giant honey bee Apis dorsata. Apidologie, 2012, 43 (6), pp.761-770. 10.1007/s13592-012-0150-0 . hal-01003670

\section{HAL Id: hal-01003670 \\ https://hal.science/hal-01003670}

Submitted on 1 Jan 2012

HAL is a multi-disciplinary open access archive for the deposit and dissemination of scientific research documents, whether they are published or not. The documents may come from teaching and research institutions in France or abroad, or from public or private research centers.
L'archive ouverte pluridisciplinaire HAL, est destinée au dépôt et à la diffusion de documents scientifiques de niveau recherche, publiés ou non, émanant des établissements d'enseignement et de recherche français ou étrangers, des laboratoires publics ou privés. 


\title{
No evidence that habitat disturbance affects mating frequency in the giant honey bee Apis dorsata
}

\author{
Atsalek RattanawanneE ${ }^{1}$, Chanpen ChanchaO ${ }^{1}$, Siriwat Wongsiri ${ }^{1}$, \\ Benjamin P. OLDROYD ${ }^{2}$ \\ ${ }^{1}$ Department of Biology, Faculty of Science, Chulalongkorn University, Bangkok 10330, Thailand \\ ${ }^{2}$ Behaviour and Genetics of Social Insects Laboratory, School of Biological Sciences, A12, University of Sydney, \\ Camperdown 2006 NSW, Australia
}

Received 25 January 2012 - Revised 28 April 2012 - Accepted 31 May 2012

\begin{abstract}
The giant honey bee (Apis dorsata) is a keystone pollinator within Asian lowland forests. Across its range, A. dorsata populations are impacted by heavy hunting pressure and habitat disturbance. These pressures have the potential to significantly impact the genetic structure of populations, particularly the ability of queens to find a large number of genetically diverse drones for mating. Here, we compare queen mating frequency and allelic diversity between colonies sampled in disturbed and undisturbed areas in Thailand. Microsatellite analysis of 18 colonies in 6 aggregations showed no significant difference in paternity frequency at disturbed and undisturbed habitats. Measures of $F_{\mathrm{ST}}$ and genetic differentiation between aggregations were not significantly different from zero $(P>0.05)$; measures of allelic diversity showed no differences between disturbed and undisturbed sites, and there was no evidence of population structuring based on the program STRUCTURE. Our findings suggest, surprisingly, that habitat disturbance has no effect on the mating frequency, genetic diversity, or population connectedness. This suggests that the mating behavior of $A$. dorsata is robust to anthropogenic changes to the landscape.
\end{abstract}

Apis dorsata / microsatellite / mating frequencies / colony aggregation / habitat disturbance

\section{INTRODUCTION}

The giant honey bee, Apis dorsata Fabricius, 1793, is distributed from the Indian subcontinent to Southeast Asia (Ruttner 1988). Colonies construct a massive single-comb nest, usually hanging in high, inaccessible places (e.g., beneath tall tree branches, cliff overhangs, and the eaves of a building) (Oldroyd and Wongsiri 2006). The species is heavily hunted throughout its range for

Electronic supplementary material The online version of this article (doi:10.1007/s13592-012-0150-0) contains supplementary material, which is available to authorized users.

Corresponding author: A. Rattanawannee, at_2912@yahoo.com

Manuscript editor: David Tarpy honey, wax, and brood, providing an important source of household income to many local people (Lahjie and Seibert 1990; Nath et al. 1994; Soman and Kshirsagar 1991; Strickland 1982).

The ecology and behaviour of $A$. dorsata differs substantially from the other Apis species (Moritz et al. 1995; Oldroyd and Wongsiri 2006; Paar et al. 2004). Colonies are often found in dense aggregations, sometimes with over 200 colonies present on a single tree or rock face (Oldroyd et al. 2000), often separated by only a few centimetres (Paar et al. 2004). A. dorsata is a peripatetic species, with colonies frequently undergoing a seasonal migration between nesting sites. Colonies usually occupy a nest site for 34 months (Paar et al. 2004). At the end of this period, colonies abscond to an alternative nesting 
or bivouac site, leaving an empty comb. Absconding swarms probably migrate between locations with different blooming seasons (Crane et al. 1993; Dyer 2002; Itioka et al. 2001; Koeniger and Koeniger 1980; Liu et al. 2007; Sheikh and Chetry 2000). Nesting sites are often reoccupied annually for decades (Oldroyd et al. 2000; Oldroyd and Wongsiri 2006).

Like other Apis species, the mating of virgin queens and drones in $A$. dorsata takes place during flight at some distance from the colony. Virgin queens and drones leave their colonies at dusk, fly to well-defined drone congregation areas (DCAs), and return 15-30 min later (Koeniger et al. 1994; Rinderer et al. 1993; Tan et al. 1999). A. dorsata virgin queens undertake 2 to 4 mating flights (Tan et al. 1999). It is unknown if all the drones from all colonies within an aggregation area fly to a single DCA or if several aggregations service the same DCA. However, Kraus et al. (2005) showed that the temporal genetic structure of an A. dorsata DCA showed significant genetic differentiation across three sampling days, supporting the hypothesis that the DCA was occupied by at least two subpopulations every day but in varying proportions. In addition, the overall effective population size $\left(N_{\mathrm{e}}\right)$ was estimated to be as high as 140 colonies. This suggests that drones from the majority of colonies within the recruitment range of this DCA were represented (Kraus et al. 2005).

All Apis species have a high but variable level of polyandry (Oldroyd et al. 1998; Palmer and Oldroyd 2000; Strassmann 2001; Tarpy et al. 2004). Extreme paternity frequency in $A$. dorsata was first reported by Moritz et al. (1995). They found that queens mated on average with $30.17 \pm 5.98$ drones with a range from 19 to 53, while the average effective number of matings (i.e., corrected for variance in paternity skew between males) was $25.56 \pm$ 11.63. Similarly, Oldroyd et al. (1996) reported that $A$. dorsata queens mated on average with $26 \pm 5.42$ drones and the mean effective mating frequency was $19.96 \pm 6.63$. Wattanachaiyingcharoen et al. (2003), who genotyped a larger sample size per colony, found 47 to 102 subfamilies per colony and an effective mating frequency ranged between 26.9 and 88.5. This indicates that there is a wide range of extreme mating frequencies in this species (Wattanachaiyingcharoen et al. 2003).

The mating biology of $A$. dorsata, particularly the extreme mating frequency and the brief but multiple mating flights at dusk, suggests that $A$. dorsata queens and their offspring colonies may be placed at a fitness disadvantage if young queens are unable to locate nearby DCAs with large numbers of genetically diverse drones (Oldroyd et al. 1995, 2000). Genetic diversity within colonies has multiple fitness benefits for honey bees, including increased disease resistance (Palmer and Oldroyd 2000; Seeley and Tarpy 2007; Tarpy and Seeley 2006), improved task allocation (Jones et al. 2004; Mattila and Seeley 2007, 2011; Oldroyd and Fewell 2007), and increased brood viability (Page 1980). Indeed, colony aggregations in Apis may have evolved in order to facilitate mating with genetically diverse drones (McNally and Schneider 1996; Oldroyd et al. 1995, 2000).

We hypothesized that anthropogenic disturbance to the landscape might influence the mating biology of $A$. dorsata populations, reducing the number and genetic diversity of males available to queens for mating. To test this hypothesis, we estimated the degree of genetic variation and the level of polyandry within and between $A$. dorsata colonies in disturbed and undisturbed areas of Thailand to assess whether habitat disturbance has an adverse effect on the mating frequency in this iconic species.

\section{MATERIALS AND METHODS}

\subsection{Study sites and sample collection}

Aggregations of $A$. dorsata were located in disturbed and undisturbed in northern Thailand (Table I; Figure 1). We defined a disturbed habitat as an area substantially cleared for agricultural purposes. Undisturbed habitats were defined as a significant area of primary forest that had not been harvested. The aggregations studied were 
Table I. Sample locations and number of $A$. dorsata colonies present in each of six aggregations in Thailand.

\begin{tabular}{|c|c|c|c|c|}
\hline No. & Sampling location & Coordinate & Habitat type & $\begin{array}{l}\text { Observed } \\
(n \text { colonies })\end{array}$ \\
\hline 1 & Nan (north) & $\begin{array}{l}19^{\circ} 10.24^{\prime} \mathrm{N} \\
100^{\circ} 55.41^{\prime} \mathrm{E}\end{array}$ & $\begin{array}{l}\text { Disturbed: urban area and surrounded } \\
\text { by rice fields }\end{array}$ & 41 \\
\hline 2 & Sakon Nakhon (northeast) & $\begin{array}{l}16^{\circ} 52.23^{\prime} \mathrm{N} \\
103^{\circ} 56.28^{\prime} \mathrm{E}\end{array}$ & Disturbed: agricultural area (rice field) & 20 \\
\hline 3 & Chaing Rai (north) & $\begin{array}{l}20^{\circ} 17.162^{\prime} \mathrm{N} \\
99^{\circ} 48.88^{\prime} \mathrm{E}\end{array}$ & $\begin{array}{l}\text { Disturbed: urban area and surrounded by } \\
\text { rice fields }\end{array}$ & 18 \\
\hline 4 & Tak (northwest) & $\begin{array}{l}17^{\circ} 01.06^{\prime} \mathrm{N} \\
98^{\circ} 56.57^{\prime} \mathrm{E}\end{array}$ & Undisturbed: Mae Tuen National Park & 23 \\
\hline 5 & Tak (northwest) & $\begin{array}{l}17^{\circ} 03.56 \mathrm{~N} \\
98^{\circ} 56.23^{\prime} \mathrm{E}\end{array}$ & Undisturbed: Mae Tuen National Park & 21 \\
\hline 6 & Nan (north) & $\begin{array}{l}19^{\circ} 11.21^{\prime} \mathrm{N} \\
100^{\circ} 57.48^{\prime} \mathrm{E}\end{array}$ & Undisturbed: Phu Ka National Park & 28 \\
\hline
\end{tabular}

located at least $2 \mathrm{~km}$ within the borders of the defined habitat type. Koeniger et al. (1994) estimated, based on mating flight durations (Koeniger et al. 1994; Rinderer et al. 1993; Tan et al. 1999), that the typical distance that a drone might fly to a DCA is approximately $700 \mathrm{~m}$. Thus, $2 \mathrm{~km}$ is sufficient to ensure that the drones and queens encountered the appropriate conditions on their mating flights.

A colony aggregation was defined as a group of colonies assembled on a single tree or building, including any solitary nests nearby $(<40 \mathrm{~m})$ the main group (Paar et al. 2004). We collected adult workers from 6 aggregations (3 aggregations in each habitat type) (Table I). We sampled at least 300 workers ( 3 colonies per aggregation) from the curtain of bees on the lower edge of the comb. Samples were collected by local honey hunters who we paid to climb the trees or building. All samples were taken carefully in the late evening without causing workers to take flight from the nest, thereby minimizing drift between colonies (Paar et al. 2002, 2004). Sampled workers were preserved in $95 \%(v / v)$ ethanol until used for DNA extraction. The number of $A$. dorsata colonies in each particular aggregation was counted and the location recorded using a GPS.

\subsection{DNA extraction and genotyping}

DNA was extracted from the hind leg of each individual worker bee using a $5 \%$ Chelex solution (Walsh et al. 1991). The microsatellite target sequen- ces were amplified by multiplex polymerase chain reactions (PCR) with fluorescently labeled primers. The microsatellite loci used were A14, A76, A88, and BI225 (Estoup et al. 1994, 1993; Solignac et al. 2007). Samples containing no DNA were included in all plates as negative controls. We then resolved PCR products in a 3130xl Genetic Analyzer (Applied Biosystems, California). Resultant data files were analyzed to determine allele size using GENEMAPPER software (Applied Biosystems).

\subsection{Reconstruction of queen genotypes and identifying patrilines}

The genotype of the queen heading each colony was inferred from the worker genotypes (Oldroyd et al. 2000, 1996). We excluded any worker that did not carry a queen allele as a drifted individual. After the genotype of the queen was determined, the genotype of the fathering drone was determined for each worker by subtraction (Oldroyd and Wongsiri 2006). Where the paternal allele could not be distinguished from the maternal allele, paternity was allocated according to the proportion of homozygotes in the sample (Oldroyd et al. 1997).

\subsection{Genetic diversity measures}

The data were evaluated with the software packages GENEPOP 4.0.10 (Rousset 2008) and STRUC- 
Figure 1. Sampling sites for A. dorsata in Thailand. Numbers correspond to those in Table I.

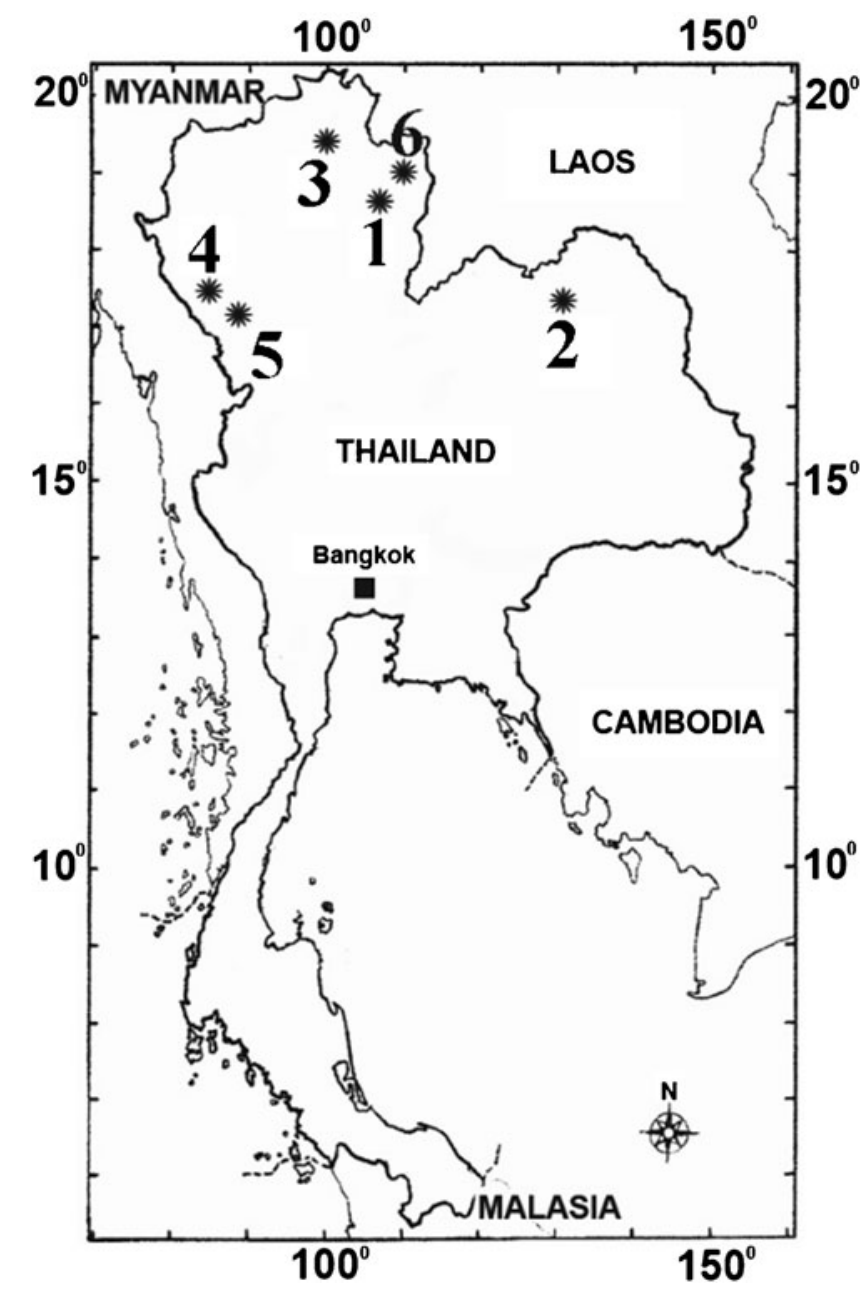

TURE 2.3.1 (Hubisz et al. 2009; Pritchard et al. 2000). All analyses were carried out with the inferred queen genotypes only (Paar et al. 2004). The number of alleles, number of effective alleles, allele frequencies, and observed $\left(H_{0}\right)$ and expected $\left(H_{\mathrm{e}}\right)$ heterozygosity (according to Hardy-Weinberg equilibrium assumptions) of each microsatellite locus were calculated using the GENEPOP, as were exact tests for Hardy-Weinberg equilibrium at each locus and genotypic linkage disequilibrium. We also used GENEPOP to test for genetic differentiation and genetic distance $\left(F_{\mathrm{ST}}\right)$ between aggregations.

The program STRUCTURE was used to estimate the most likely number of sub populations in our overall population (Delaney et al. 2009; Pritchard et al. 2000; Rueppell et al. 2011). This program uses a Bayesian model to probabilistically allocate individuals into one of $\mathrm{K}$ sub-populations assuming that subpopulations have different allele frequencies (Pritchard et al. 2000). The parameter set was programmed for independent alleles and individuals with and without assuming population admixture. The program was asked to place individuals from all six aggregations into one, two, three, four, five, and six groups. We used a burn-in period and iteration number of 10,000 each and assumed correlated allele frequencies, with program defaults for all other parameters and options (Pritchard et al. 2000; Rueppell et al. 2011). The best estimate of number of populations $(K)$ was determined by looking at the 
values of the probability of the Bayesian model $[\operatorname{Ln} P$ $(X / K)$, abbreviated as $\operatorname{Ln}(P)$ in the following] and the value of $\alpha$.

\subsection{Mating frequency determination}

Effective mating frequency $\left(m_{\mathrm{e}}\right)$ within each colony with a correction for finite sample size was calculated according to Tarpy and Nielsen (2002). Average relatedness, $r$, weighted according to the relative proportions of each subfamily and corrected for finite sample size, was calculated for each colony according to Oldroyd and Moran (1983).

In order to make valid comparison of mating frequency between disturbed and undisturbed sites, and for comparison with previous studies of mating frequency in $A$. dorsata, observed paternity frequency, $k$, was adjusted to a common sample size of $n$ according to Franck et al. (2000). For each comparison, we set $n$ to the sample size of the colony with the lowest sample size.

\subsection{Non-detection and non-sampling errors}

The number of patrilines in a colony may be underestimated if a patriline goes undetected if two or more drones involved in the mating have identical genotypes (non-detection error), or if a patriline is not represented in the sample (non-sampling error). The probability that two drones in a population in HardyWeinberg will have identical genotypes at all loci studied, and thus be genetically indistinguishable (non-detection error, nd) was calculated according to Foster et al. (1999). The probability of not sampling a particular patriline, ns, was also calculated according to Foster et al. (1999).

\subsection{Statistical tests}

We tested for paternity skew for each colony using $G$ tests (Palmer et al. 2001). We compared paternity frequencies, effective paternity frequency, estimates of paternity frequency with common sample size $n=87$, and intra-colonial relatedness between disturbed and undisturbed sites using ANOVA, with aggregation nested within habitat type. We also compared estimates of effective paternity frequency found in this study with those observed by Wattanachaiyingcharoen et al. (2003) and Oldroyd et al. (1996) using the independent samples $t$ test using a common sample size $n=87$ and $42\left(k_{87}\right.$ and $k_{42}$,) respectively.

\section{RESULTS}

\subsection{Population genetic structure}

The number of alleles, number of effective alleles, allele frequencies, and observed $\left(H_{0}\right)$ and expected $\left(H_{\mathrm{e}}\right)$ heterozygosity are shown in Table SI. The sampled aggregations did not show any sub-structuring as shown by the Bayesian-Markov assignment algorithm implemented in STRUCTURE. $K=1$ was the most strongly supported number of populations [Ln $(P)=-297.1$ and $\operatorname{Var} \operatorname{Ln}(P)=9.2]$ when assuming no admixture. There was no significant deviation from Hardy-Weinberg equilibrium for any one locus $(P>0.05)$ or over all loci $(P=$ 0.96). There was no evidence of linkage disequilibrium between any pair of loci at the population level $(P>0.05)$. Furthermore, no individual aggregation showed significant linkage disequilibrium $(P>0.05)$. All $F_{\mathrm{ST}}$ values between aggregations were not significantly different from zero $(P>0.05)$. Tests for allele frequency differences (genic differentiation) between aggregations also revealed no significant differences.

\subsection{Paternity frequency in disturbed and undisturbed sites}

The four microsatellite loci (A14, A76, A88, and BI225) had sufficient variability to differentiate the parental genotypes within the colonies (SI).

Observed mating frequency, $k,\left(F_{1,12}=\right.$ $0.0004, P=0.984)$, effective mating frequency, $m_{\mathrm{e}}\left(F_{1,12}=0.232, P=0.639\right)$, mating frequency corrected for sample size, $k_{87}\left(F_{1,12}=0.097, P=\right.$ $0.760)$ and intra-colonial relatedness, $r,\left(F_{1,12}=\right.$ $0.480, P=0.502)$ were not significantly different between disturbed and undisturbed sites (Table II). We found significant paternity skew in all colonies studied $(P<0.01)$. 
The probability of failing to detect a patriline due to genetically identical inseminating drones (nd) (Boomsma and Ratnieks 1996) was 0.0018 based on allele frequencies from the entire study. This means that fewer than two fathering males were expected to be undetected in all 18 colonies (Table II).

A patriline that is well represented in a colony has a low probability of not being sampled. For our sample size, the probability of not sampling a patriline represented by $1 / 20$ of the worker population ranged from 0.0001 to 0.0037 . However, a patriline that represented by only a small proportion of a colony's worker population had a higher probability of non-sampling. For example, if a patriline was represented by 1/50 of worker population, the probability of not sampling a worker from this patriline ranged from 0.027 to 0.172 with the sample sizes used in the present study. In some patrilines, only one worker was identified, suggesting that some patrilines went undiscovered.

We found no significant difference in deduced paternity frequency $\left(k_{87}\right)$ and effective paternity frequency $\left(m_{\mathrm{c}}\right)$ between disturbed and undisturbed sites $\left(F_{1,12}=0.097, P=0.760\right.$, and $F_{1,12}=$ $0.232, P=0.639$, respectively). Additionally, there was no significant difference in $k_{87}$ and $m_{\mathrm{c}}$ values between aggregations within habitat types $\left(F_{5,12}=0.128, P=0.983\right.$, and $F_{5,12}=0.399$, $P=0.841$, respectively).

The frequency of drifted workers was very low, ranging from 0 to $2.42 \%$ with an average of $0.83 \%(\mathrm{SE}=0.21)$ (Table II).

We found significantly lower $k_{87}$ and $m_{\mathrm{c}}$ values than those found by Wattanachaiyingcharoen et al. (2003) $(P<0.0012$-tail $t$ test) (Table II). We also found no significant difference in effective paternity frequency from that found by Oldroyd et al. (1996) $(P=0.057$, two-tail $t$ test $)$.

\section{DISCUSSION}

\subsection{Mating frequency and environmental disturbance}

Our study shows that there is no significant difference in the mating frequency of $A$. dorsata queens sampled in disturbed and undisturbed habitats. This indicates that habitat disturbance has no measurable effect on mating frequency in A. dorsata, and so our hypothesis that mating frequency and intra-colonial genetic diversity might be adversely affected in disturbed areas can be rejected.

Franck et al. (2000) suggested that the documented differences in mating frequency between populations of Apis mellifera probably arise from variance in the risks incurred on mating flights. The cost of multiple mating principally depends on the number and duration of mating flights (Franck et al. 2000), as flights during bad weather are more likely to result in queen death and will reduce the likely levels of polyandry (El-Niweiri and Moritz 2011; Kraus et al. 2004; Neumann et al. 1999; Schluns et al. 2005). Franck et al. (2000) postulated that $A$. mellifera queens modulate the number of mating flights they undertake according to prevailing environmental conditions. For example, if a queen is obliged to mate during rainy weather, it most likely reduces the frequency and duration of mating flights, thereby reducing the genetic diversity of sperm in her spermatheca. Oldroyd et al. (1995) proposed that the genus-wide tendency for honey bee colonies to be aggregated may be driven by the need for proximity to drone congregation areas, thereby facilitating mating with a diversity of males. We suggested that this is especially the case in $A$. dorsata (Oldroyd et al. 2000) where mating flights are brief (Rinderer et al. 1993). However, the results of the present study revealed no difference in the mating frequency of $A$. dorsata queens in disturbed and undisturbed environments, suggesting that there is no significant difference in mating opportunities at disturbed and undisturbed sites.

Our results suggest that current levels forest clearing in Thailand to make way for agricultural and urban areas has not had a significant effect on the population structure of $A$. dorsata, or on the mating frequency. A potential reason for this is that there is frequent exchange of colonies between forested and cleared areas. Thus, a queen that mated in a disturbed habitat 


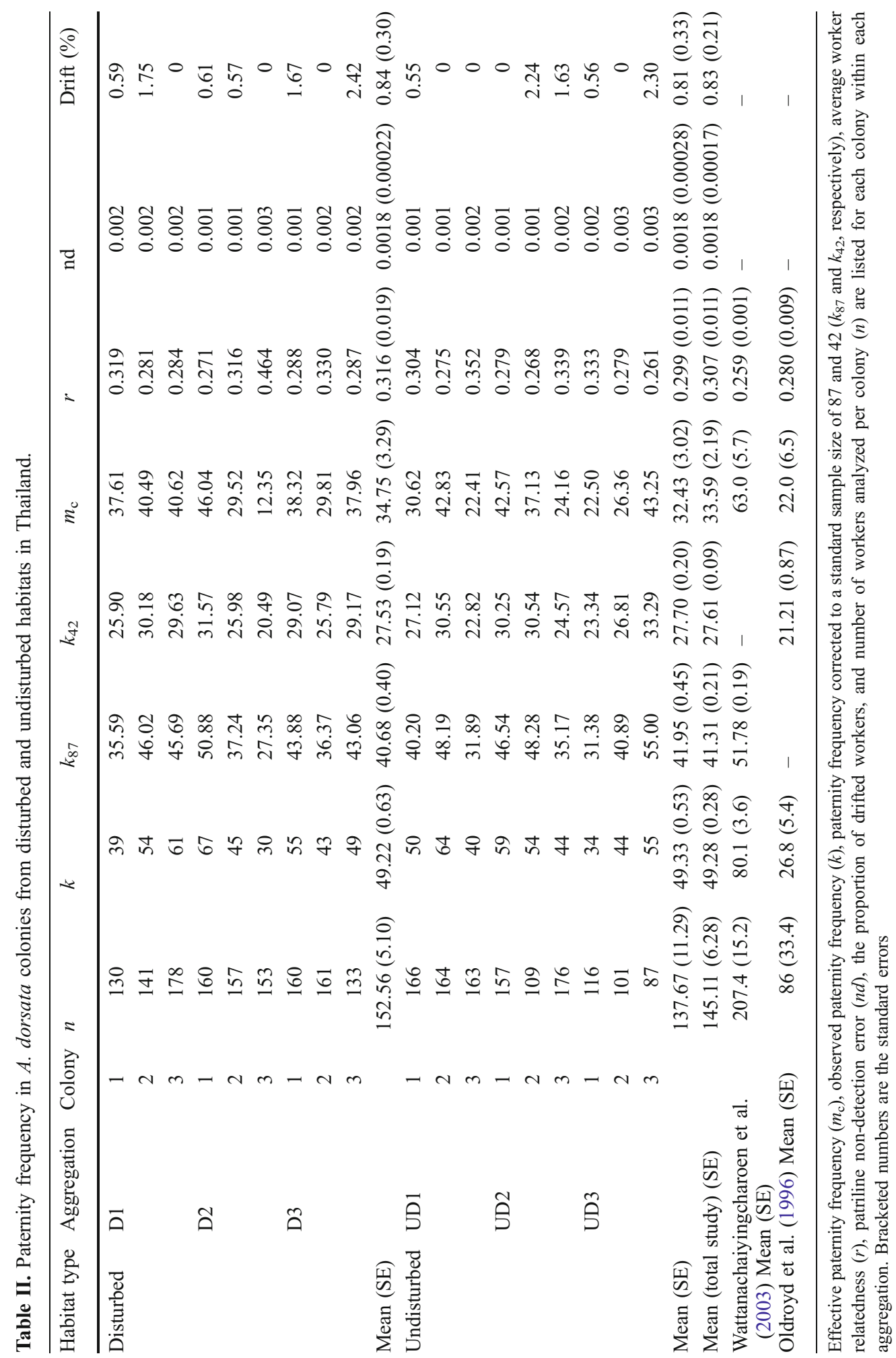


may found a colony in an undisturbed habitat and vice versa.

\subsection{Genetic structure of $A$. dorsata in Thailand}

There was no significant difference in the degree of genic differentiation between aggregations in disturbed and undisturbed habitats showed, implying that there are no significant barriers to gene flow between disturbed and undisturbed habitats. Rattanawannee et al. (2012) found no genetic differentiation in $A$. dorsata populations at local scales in northwestern Thailand. These results support the theory that the long distance migratory behavior of $A$. dorsata allows it to tolerate habitat fragmentation (Rattanawannee et al. 2012). Furthermore, there was no genetic differentiation among aggregations, suggesting that matings may occur between aggregations (Rattanawannee et al. 2012), and that migrating swarms that join an aggregation come from diverse sources (Paar et al. 2004).

\subsection{Levels of polyandry in $A$. dorsata}

Our results confirm that $A$. dorsata queens have an extremely high mating frequency (Moritz et al. 1995; Oldroyd et al. 1996; Wattanachaiyingcharoen et al. 2003). The observed mating frequencies for queens in this study ranged from 30 to 67 . The average effective mating frequency in this study $(33.59 \pm 2.19)$ was not significantly different from that found by Oldroyd et al. (1996) $(25.60 \pm 11.60)$, but is considerably lower than that observed by Wattanachaiyingcharoen et al. (2003) (63.0 \pm 5.70$)$. Despite our correction for sample size, our estimate of mating frequency may be underestimated due to undetected fathers. Wattanachaiyingcharoen et al. (2003) genotyped up to 288 workers per colony, providing better sampling coverage.

In conclusion, we have shown that the environment disturbance has no effect on mating frequency in A. dorsata. We confirm that the giant honey bee populations are panmictic despite current levels of bee hunting and habitat fragmentation. This is likely due to the highly mobile nature of the species, as well as their high reproductive rates.

\section{ACKNOWLEDGMENTS}

This research was financially supported by the Program Strategic Scholarships for Frontier Research Network for the Joint Ph.D. Program Thai Doctoral degree from the Commission on Higher Education (Thailand) (14/2550), the 90th anniversary of Chulalongkorn University Fund (Ratchadaphiseksomphot Endowment Fund) and the Science for Locale Project under the Chulalongkorn University Centenary Academic Development Plan (2008-2012).

Les modifications de son habitat ne semblent pas affecter la fréquence d'accouplement de l'abeille géante Apis dorsata

Apis dorsata / microsatellite / fréquence d'accouplement / agrégation des colonies / perturbation de l'habitat

Es gibt keine Hinweise darauf, dass die Paarungshäufigkeit der Riesenhonigbiene, Apis dorsata, von Störungen des Lebensraums beeinflusst wird

Apis dorsata / Mikrosatelliten / Paarungshäufigkeit / Nestaggregation / Störung des Lebensraums

\section{REFERENCES}

Boomsma, J.J., Ratnieks, F.L.W. (1996) Paternity in eusocial Hymenoptera. Phil. Trans. R. Soc. Lond. B. 351, 947-975

Crane, E., van Luyen, V., Mulder, V., Ta, T.C. (1993) Traditional management system for Apis dorsata in submerged forests in southern Vietnam and central Kalimantan. Bee World 74, 27-40

Delaney, D.A., Meixner, M.D., Schiff, N.M., Sheppard, W.S. (2009) Genetic characterization of commercial honey bee (Hymeno-ptera: Apidae) populations in the United States by using mitochondrial and microsatellite markers. Ann. Entomol. Soc. Am. 102, 666-673

Dyer, F.C. (2002) The biology of the dance language. Ann. Rev. Entomol. 47, 917-949

El-Niweiri, M.A.A., Moritz, R.F.A. (2011) Mating in the rain? Climatic variance for polyandry in the honeybee (Apis mellifera jemenitica). Popul. Ecol. 53, 421-427 
Estoup, A., Solignac, M., Harry, M., Cornuet, J.M. (1993) Characterization of $(\mathrm{GT})_{\mathrm{n}}$ and $(\mathrm{CT})_{\mathrm{n}}$ microsatellites in two insect species: Apis mellifera and Bombus terrestris. Nucleic Acids Res. 21, 1427-1431

Estoup, A., Solignac, M., Cornuet, J.M. (1994) Precise assessment of the number of patrilines and of genetic relatedness in honeybee colonies. Proc. R. Soc. B. 258, 1-7

Foster, K.R., Seppa, P., Ratnieks, F.L.W., Thoren, P.A. (1999) Low paternity in the hornet Vespa crabro indicates that multiple mating by queens is derived in vespine wasps. Behav. Ecol. Sociobiol. 46, 252-257

Franck, P., Koeniger, N., Lahner, G., Crewe, R.M., Solignac, M. (2000) Evolution of extreme polyandry: an estimate of mating frequency in two African honeybee subspecies, Apis mellifea monticola and A.m. scutellata. Insectes Soc. 47, 364-370

Hubisz, M.J., Falush, D., Stephens, M., Pritchard, J.K. (2009) Inferring weak population structure with the assistance of sample group information. Mol. Ecol. Res. 9, 1322-1332

Itioka, T., Inoue, T., Kaliang, H., Kato, M., Nagamitsu, T., Momose, K., Sakai, S., Yumoto, T., Mohamad, S.U., Hamid, A.A., Yamane, S. (2001) Six-year population fluctuation of giant honey bee Apis dorsata (Hymenoptera: Apidae) in tropical lowland dipterocarp forest in Sarawak. Ann. Entomol. Soc. Am. 94, 545-549

Jones, J.C., Myerscough, M.R., Graham, S., Oldroyd, B.P. (2004) Honey bee nest thermoregulation: diversity promotes stability. Science 305, 402-404

Koeniger, N., Koeniger, G. (1980) Observations and experiments on migration and dance communication of Apis dorsata in Sri Lanka. J. Apic. Res. 19, 21-34

Koeniger, N., Koeniger, G., Tingek, S., Kalitu, A., Mardan, M. (1994) Drones of Apis dorsata (Fabricius 1793) congregate under the canopy of tall emergent trees in Borneo. Apidologie 25, 249-264

Kraus, F.B., Neumann, P., van Praagh, J., Moritz, R.F.A. (2004) Sperm limitation and the evolution of extreme polyandry in honeybees (Apis mellifera L.). Behav. Ecol. Sociobiol. 55, 494-501

Kraus, F.B., Koeniger, N., Tingek, S., Moritz, R.F.A. (2005) Temporal genetic structure of a drone congregation area of the giant Asian honeybee (Apis dorsata). Naturwissenschaften 92, 578-581

Lahjie, A.M., Seibert, B. (1990) Honey gathering by people in the interior of East Kalimantan. Bee World 71, 153-157

Liu, F., Roubik, D.W., He, D., Li, J. (2007) Old comb for nesting site recognition by Apis dorsata? Field experiments in China. Insectes Soc. 54, 424-426

Mattila, H.R., Seeley, T.D. (2007) Genetic diversity in honey bee colonies enhances productivity and fitness. Science 317, 362-364

Mattila, H.R., Seeley, T.D. (2011) Does a polyandrous honeybee queen improve through patriline diversity the activity of her colony's scouting foragers? Behav. Ecol. Sociobiol. 65, 799-811

McNally, L.C., Schneider, S.S. (1996) Spatial distribution and nesting biology of colonies of the African honey bee Apis mellifera scutellata (Hymenoptera: Apidae) in Botswana, Africa. Environ. Entomol. 25, 643-652

Moritz, R.F.A., Kryger, P., Koeniger, N., Estoup, A., Tingek, S. (1995) High degree of polyandry in Apis dorsata queens detected by DNA microsatellite variability. Behav. Ecol. Sociobiol. 37, 357-363

Nath, S., Roy, P., Leo, R., John, M. (1994) Honeyhunters and beekeepers of Tamil Nadu, a survey document. Keystone, Pondicherry

Neumann, P., Moritz, R.F.A., van Praagh, J. (1999) Queen mating frequency in different types of honey bee mating apiaries. J. Apic. Res. 38, 11-18

Oldroyd, B.P., Fewell, J.H. (2007) Genetic diversity promotes homeostasis in insect colonies. Trends Ecol. Evol. 22, 408-413

Oldroyd, B.P., Moran, C. (1983) Heritability of worker characters in the honeybee (Apis mellifera). Aust. J. Biol. Sci. 36, 323-332

Oldroyd, B.P., Wongsiri, S. (2006) Asian honey bees. Biology, conservation and human interaction. Harvard University Press, Cambridge

Oldroyd, B., Smolenski, A., Lawler, S., Estoup, A., Crozier, R. (1995) Colony aggregation in Apis mellifera L. Apidologie 26, 119-130

Oldroyd, B.P., Smolenski, A.J., Cornuet, J.M., Wongsiri, S., Estoup, A., Rinderer, T.E., Crozier, R.H. (1996) Levels of polyandry and intracolonial genetic relationships in Apis dorsata (Hymenoptera: Apidae). Ann. Entomol. Soc. Am. 89, 276-283

Oldroyd, B.P., Clifton, M.J., Wongsiri, S., Rinderer, T.E., Sylvester, H.A., Crozier, R.H. (1997) Polyandry in the genus Apis, particularly Apis andreniformis. Behav. Ecol. Sociobiol. 40, 17-26

Oldroyd, B.P., Clifton, M.J., Parker, K., Wongsiri, S., Rinderer, T.E., Crozier, R.H. (1998) Evolution of mating behavior in the genus Apis and an estimate of mating frequency in Apis cerana (Hymenoptera: Apidae). Ann. Entomol. Soc. Am. 91, 700-709

Oldroyd, B.P., Osborne, K.E., Mardan, M. (2000) Colony relatedness in aggregations of Apis dorsata Fabricius (Hymenoptera, Apidae). Insectes Soc. 47, 94-95

Paar, J., Oldroyd, B.P., Huettinger, E., Kastberger, G. (2002) Drifting of workers in nest aggregations of the giant honeybee Apis dorsata. Apidologie 33, 553-561

Paar, J., Oldroyd, B.P., Huettinger, E., Kastberger, G. (2004) Genetic structure of an Apis dorsata population: the significance of migration and colony aggregation. J. Hered. 95, 119-126 
Page, R.E. (1980) The evolution of multiple mating behavior by honey bee queens Apis mellifera L. Genetics 96, 263-273

Palmer, K.A., Oldroyd, B.P. (2000) Evolution of multiple mating in the genus Apis. Apidologie 31, 235-248

Palmer, K., Oldroyd, B., Franck, P., Hadisoesilo, S. (2001) Very high paternity frequency in Apis nigrocincta. Insectes Soc. 48, 327-332

Pritchard, J.K., Stephens, M., Donnelly, P. (2000) Inference of population structure using multilocus genotype data. Genetics 155, 945-959

Rattanawannee, A., Chanchao, C., Lim, J., Wongsiri, S., Oldroyd, B.P. (2012) Genetic structure of a giant honey bee (Apis dorsata) population in northern Thailand: implications for conservation. Insect Conserv. Divers.. doi:10.1111/j.1752-4598.2012.00193.x

Rinderer, T.E., Oldroyd, B.P., Wongsiri, S., Sylvester, H.A., Deguzman, L.I., Potichot, S., Sheppard, W.S., Buchmann, S.L. (1993) Time of drone flight in 4 honey bee species in south-eastern Thailand. J. Apic. Res. 32, 27-33

Rousset, F. (2008) GENEPOP' 07: a complete reimplementation of the GENEPOP software for Windows and Linux. Mol. Ecol. Resour. 8, 103-106

Rueppell, O., Hayes, A.M., Warrit, N., Smith, D.R. (2011) Population structure of Apis cerana in Thailand reflects biogeography and current gene flow rather than Varroa mite association. Insectes Soc. 58, 445-452

Ruttner, F. (1988) Biogeography and taxonomy of honey bee. Springer Verlag, Berlin

Schluns, H., Moritz, R.F.A., Neumann, P., Kryger, P., Koeniger, G. (2005) Multiple nuptial flights, sperm transfer and the evolution of extreme polyandry in honeybee queens. Anim. Behav. 70, 125-131

Seeley, T.D., Tarpy, D.R. (2007) Queen promiscuity lowers disease within honeybee colonies. Proc. R. Soc. B. 274, 67-72
Sheikh, M.S., Chetry, G. (2000) Distribution of honey bees in Assam. Environ. Ecol. 18, 234-236

Solignac, M., Mougel, F., Vautrin, D., Monnerot, M., Cornuet, J.M. (2007) A third-generation microsatellitebased linkage map of the honey bee, Apis mellifera, and its comparison with the sequence-based physical map. Genome Biol. 8, R66

Soman, A.G., Kshirsagar, K.K. (1991) Preliminary survey on the rockbee (Apis dorsata F.) and some observations on the traditional methods of honey hunting. Indian Bee J. 53, 1-4

Strassmann, J. (2001) The rarity of multiple mating by females in the social Hymenoptera. Insectes Soc. 48, $1-13$

Strickland, S.S. (1982) Honey hunting by the Gurungs of Nepal. Bee World 63, 153-161

Tan, N.Q., Maardan, M., Thai, P.H., Chinh, P.H. (1999) Observations on multiple mating flights of Apis dorsata queens. Apidologie 30, 339-346

Tarpy, D.R., Nielsen, D.I. (2002) Sampling error, effective paternity, and estimating the genetic structure of honey bee colonies (Hymenoptera: Apidae). Ann. Entomol. Soc. Am. 95, 513-528

Tarpy, D.R., Seeley, T.D. (2006) Lower disease infections in honeybee (Apis mellifera) colonies headed by polyandrous vs monandrous queens. Naturwissenschaften 93, 195-199

Tarpy, D.R., Nielsen, R., Nielsen, D.I. (2004) A scientific note on the revised estimates of effective paternity frequency in Apis. Insectes Soc. 51, 203-204

Walsh, P.S., Metzger, D.A., Higuchi, R. (1991) Chelex100 as a medium for simple extraction of DNA for PCR-based typing fromforensic material. Biotechniques 10, 506-513

Wattanachaiyingcharoen, W., Oldroyd, B.P., Wongsiri, S., Palmer, K., Paar, R. (2003) A scientific note on the mating frequency of Apis dorsata. Apidologie 34, 85-86 